11 Starrett, W. C., Ecology, 31, 216 (1950)

${ }^{12}$ Varley, G. C., J. Anim. Ecol., 31, 167 (1962).

${ }^{13}$ Larkin, P. A., J. Fish. Res. Bd. Can., 13, 327 (1956).

Swingle, H. S., and Smith, E. V., Alabama Agric. Exp. Sta. Bull. No. 254 (1950)

${ }^{15}$ Beckman, W. C., Amer. Fish. Soc. Trans., 70, 143 (1940).

16 Beckman, W. C., Amer. Fish. Soc. Trans., 72, 72 (1942).

${ }^{17}$ Beckman, W. C., Amer. Fish. Soc. Trans., 78, 82 (1948).

14 Le Cren, E. D., J. Anim. Ecol., 27, 287 (1958).
10 Weatherley, A, and Nicholls, A, G. Austral. J. Mar. Freshw. Res., B, 443 (1955).

${ }^{20}$ Smith, M. W., J. Fish. Res. Bd. Can., 12, 210 (1955).

${ }^{21}$ Nelson, P. R., and Edmondson, W. T., U.S. Fish. and Wildife Serv. Bull. No. 102 (1955).

22 Ball, R. C., Amer. Fish. Soc. Trans., 78, 145 (1948).

${ }^{25}$ Andrewartha, H. G., and Birch, I. C., The Distribution and Abundance of Animals (Úniv. Chicago Press, 1954).

${ }^{24}$ Gause, G. F., The Struggle for Existence (Williams and Wilkins, 1934).

is Fryer, G. . Proc. Zool. Soc. Lond., 132, 153 (1959).

\title{
OBITUARIES
}

\section{Dr. G. H. Cunningham, C.B.E., F.R.S.}

Gordon Herriot CUnNINGHAM, pioneer in plant pathology and texonomic mycology in New Zealand and formerly director of the Plant Diseases Division, Department of Scientific and Industrial Research, died at Auckland on July 18, 1962.

Born at Moa Flat, a high country sheep station in Central Otago, New Zealand, he spent his childhood in the wide spaces of the tussock lands, which induced in him a lasting love of outdoor life. He received his early education at the local Dunrobin school and at Tapanui High School.

As a young man he gained wide practical experience in sheop farming, fruit growing and forestry work in both New Zealand and Australia. During the First World War he served with the New Zealand Expeditionary Forces, but, after being wounded during the Gallipoli campaign, he was invalided home.

Debarred by his injuries from rejoining the Armed Forces and being keenly interested in fruit growing, he joined the New Zealand Department of Agriculture as an orchard instructor in 1917, the year in which he met Madge Leslie MeGregor, whom he married the following February. Cunningham's knowledge of, and interest in, the diseases of fruit trees so much impressed the director of his Division that he was transferred (in 1918) to the Department's Biological Laboratory at Weraroa, near Levin, to specialize in plant pathology. Realizing the need for academic training, he requested permission to attend university and moved to Wellington early in 1920.

This was the beginning of an extraordinarily active career in plant pathology and systematic mycology. During the eight years he was stationed at Wellington, while fulfilling his normal duties as plant pathologist, he passed his university entrance examinations and gained the degrees of B.Sc. (1924), M.Sc. (1925) and Ph.D. (1927). He published his first book, Fungous Diseases of Fruit Trees in New Zealand (1925), wrote thirty papers on plant pathology and thirty-two on taxonomic mycology, made disesse surveys throughout the country and many excursions into the field to collect specimens for the establish. ment of a herbarium of New Zealand fungi. His taxonomic research, which included systematics and developmental studies of the Ustilaginales, Uredinales, Gasteromycetes and Polyporaceae, set a pattern for his later work within the Basidiomycetes. During the winters he visited the main fruit-growing areas to lecture to orchardists on the diseases of fruit trees. In 1924, on the recommendation of Dr. E. J. Butler, director of the Imperial Mycological Institute, London, who had visited New Zealand the previous year, he was sent to England to represent the Dominion at the first Imperial Mycological Conference.

When agricultural research was re-organized in 1928 and the Plant Research Station was formed with headquarters at Palmerston North, Cunningham was placed in charge of the Mycological Laboratory of the new institution. In the following year he attended the second Imperial Mycological Conference in London, visiting research institutions in Britain, on the Continent and in North America. This enabled him to meet most of the world's leading plant pathologists and fungous taxonomists, contacts which had a lasting influence on his work. During the eight years that he was in charge of the Mycological Laboratory he organized a team of plant pathologists to work in the fields of economic mycology, bacteriology, virology, plant physiology and plant protection. He continued his systematic mycology, and in addition to writing many taxonomic papers he published his book, The Rust Fungi of New Zealand (1931), for which he was awarded the degree of D.Sc. At the same time, he maintained a keen interest in plant pathology and published articles dealing with chemicals used for the control of plant diseases and pests. This work culminated in 1935 in the publication of a book, Plant Protection by the Aid of Therapeutants. In the same year he was awarded the Hutton Memorial Medal for research in mycological botany.

A further re-organization was made in 1936 when plant research was transferred from the Department of Agriculture to the Department of Scientific and Industrial Research. A Plant Diseases Division, responsible for plant pathology, entomology and pomological aspects of fruit growing, was formed, Cunningham becoming its director. His first task, apart from choosing a suitable site in Auckland, was to plan buildings for the new Division. A modern laboratory block on the slopes of Mt. Albert was ready for occupation in January 1938. Although much of his time was taken up in planning and organizing during this period, he still continued his research, producing a steady flow of scientific papers and reports.

With the formation of the Plant Diseases Division, the acquisition of land and erection of laboratories, Cunning. ham, for the first time in his career, had adequate facilities to pursue his ideal of creating a plant protection service adequate to the Dominion's needs. He introduced, in 1938 , a voluntary therapeutant certification scheme which revolutionized chemical control of diseases and pests in New Zealand. It was also through his encouragement and assistance that the New Zealand Fruitgrowers' Federation, Ltd., established a Fruit Tree Nursery at Levin, from which, for the past twenty years, orchardists have been able to secure pedigree fruit trees growing on improved rootstocks.

In spite of the difficulties in organizing a plant protection service, he still found time for his taxonomic studies and began to prepare the manuscript of a book on the Gasteromycetes of Australia and New Zealand. The development of the Division, however, suffered a severe setback with the outbreak of the Second World War. As a veteran of the First World War, he viewed sympathetically his staff's desire to join the Armed Services. As soon as permission could be secured, therefore, more than half his trained professional staff volun teered for active service. His own particular contribution was to the linen flax industry, which operated at that time in the Dominion.

With the War over and his officers returning from duty overseas, he set about rebuilding his plant protection organization. He also again took up his taxonomic studies, his book, The Gasteromycetes of Australia and New: 
Zealand, appearing in 1944. In 1948 he was awarded the Hector Medal, and in 1949 the C.B.E. In 1950 he was elected a Fellow of the Royal Society.

During the ten years before his retirement in 1957 at the age of sixty-five he devoted much time to the study of systematics. Although he died when he was sixty-nine, in those four years he prepared the manuscripts of one book on the Thelephoraceae and another on the Polyporaceae of Australia and New Zeraland. The former is due to appear early in 1963, while arrangements have been made to publish the latter.

Dr. Cunningham was a man of great physical and mental energy. In his youth he earned a reputation both as a boxer and as a racing motor-cyclist, and in later life became a keen mountaineer. An indefatigable collector, until his last illness he spent much time in the field gathering material for the Plant Diseases Division Mycological Herbarium which, begun by him more than forty years ago, is now one of the finest in the southern hemisphere. His work was characterized by a remarkable perception and soundness of judgment. This is shown by the fact that his early papers in both plant pathology and systematics were, even on present-day standards, of exceptional merit. In addition to 220 scientific papers, including six books, he wrote a biography on the life of Squadron Leader McGregor-Mac's Memoirs. Ho had an absorbing interest in farming with a keen desire to assist the man on the land. A delightful companion, he will be greatly missed by his many colleagues and friends throughout the world. To science his death is a very serious loss, but his huge output of work is a monument in itself. $\mathrm{He}_{\Theta}$ is survived by a wife and married daughter.

\section{E. E. Chamberlain}

\section{Prof. E. J. King}

Earl Judson KING, professor of chemical pathology in the University of London at the Postgraduate Medical School, died suddenly at his home in London on October 31 , at the age of sixty-one years.

Prof. King was born in Toronto in 1901, the son of the Rev. C. W. King. He was a student at Brandon College and then attended McMaster University, where he graduated with honours in chemistry and biology. $\mathrm{He}_{\mathrm{e}}$ then proceeded to the master's degree in chemistry and, having been awarded a National Research Council bursary, went to work with Prof. F. B. Allan in the University of Toronto, where he obtained his Ph.D. in 1926. During the following year he was research associate in the Department of Medical Research at Toronto and then entered the Banting Institute in 1927. While here he spent two periods of leave of absence - one at the Lister Institute in London and the other at the Kaiser Wilhelm Institut in Munich. He returned to Toronto as assistant professor of medical research and director of the Biochemical Section of the Banting Institute. In 1934 he was invited to become reader in pathological chemistry and head of the Chemical Pathology Department at the newly founded Postgraduate Medical School of London. $\mathrm{He}$ took up these duties in 1935 and was appointed professor of chemical pathology in 1944. Ho was admitted to the fellowship of the Royal Institute of Chemistry in 1948 and appointed an examiner in 1952. He eventually obtained the degree of D.Sc. of the University of London.

Prof. King's two major scientific interests were concerned with research on silicosis and the phosphatase enzymes. In each of these fields he gained world-wide recognition. The work on phosphatase was commenced at the Lister Institute with Robison in 1929 and later in Toronto with A. R. Armstrong he devised the well-known. method for estimating alkaline phosphatase in blood. The King-Armstrong unit has become a household name in all laboratories concerned with clinical chemistry. In this respect, it is interesting that Prof. King was the main originator of proposals to define enzyme units on a more rational basis, which would mean that the unit with which his name was associated would be abolished. The work on phosphatase could justly be regarded as the forerunner of the general use of enzymology in clinical practice as well as in clinical research.

During his period at the Postgraduate Medical School, Prof. King developed many of the micro-chemical methods now in use in clinical chemistry and did much to introduce photo-electric equipment concerned with colorimetry, flame photometry and automatic analysis. He was a constant inspiration to those who worked with him; a notable number of people who worked in his Department have achieved senior status. One of the most admirable aspects of Prof. King's character was the great trouble to which he went to help promote the interests of the junior members of his staff as well as the encouragement he gave them.

Prof. King served with distinction on a remarkably large number of committees and held many administrative appointments. He was one of the founders and the first secretary of the Canadian Biochemical Society. He was appointed sub-dean of the Postgraduate Medical School in 1944. He was secretary of the Board of Studies in Biochemistry in the University of London during 1943-46 and served as chairman from 1951 until 1955. He also served as chairman of the Committee on Clinical Chemistry of the International Union of Pure and Applied Chemistry and was president of the Biological Section. $\mathrm{He}_{\theta}$ was chairman of the International Federation of Clinical Chemistry during 1952-60 and chairman of the Central Academic Council of the British Postgraduate Medical Federation from 1952 until 1955. He was president of the British Occupational Hygiene Society (1954-55) and chairman of the Editorial Board of the Biochemical Journal from 1946 until 1952. In 1957 he became chairman and director of the Postgraduate Medical School's combined Departments of Bacteriology, Biophysics, Chemical Pathology, Hæmatology and Morbid Anatomy and Histology.

He played a great part in the formation of the Association of Clinical Biochemists; he was chairman during 1953-55 and president in 1956.

In addition to numerous scientific papers, Prof. King published Chronic Pulmonary Disease in South Wales Coalminers: III-Experimental Studies (M.R.C. special report) and was the original author of Micro-Analysis in Medical Biochemistry and co-editor (with R. H. S. Thompson) of Biochemical Disorders in Human Disease.

During the Second World War he was sector chemical pathologist in the Emergency Medical Service and consultant in pathology to the R.A.M.C. In 1945 he went to India with the rank of brigadier to act as adviser on chemical pathology.

Among numerous honours that he received were life membership of the American Association of Clinical Chemists, the Queen's Coronation Medal, honorary membership of the Canadian Physiological Society, and the Canadian Society for Clinical Chemistry. He was the recipient of a number of honorary degrees, including an honorary M.D. by both the University of Oslo and the University of Iceland. These latter were more than appropriate, since Prof. King had contributed so much to medicine.

Earl Judson King was typically colonial in his manner. $\mathrm{He}$ was always very forthright and direct, but, nevertheless, the kindliest of men, who made friends throughout the world. He was an extraordinarily good host and it was in this role that many obtained their first glimpse of the remarkable breadth of his culture.

Although during the last years of his life he suffered from serious illness, this was only allowed to interfere with his activities as little as possible.

In 1927 he married Hazel Keith, a former class-mate at Brandon College. He is survived by his wife and two daughters.
A. L. LATNER 